GRASAS Y ACEITES, 64 (5),

OCTUBRE-DICIEMBRE, 497-508, 2013

ISSN: 0017-3495

Dol: $10.3989 / g y a .012513$

\title{
Chemical, thermal and viscous characterization of high-oleic sunflower and olive pomace acid oils and derived estolides
}

\author{
By L.A. García-Zapateiro ${ }^{1,2}$, J.M. Franco ${ }^{2,3, 凶}$, C. Valencia ${ }^{2,3,}$, M.A. Delgado ${ }^{2,3}$, C. Gallegos ${ }^{2,3}$ \\ and M.V. Ruiz-Méndez ${ }^{4}$
}

\author{
${ }^{1}$ Departamento de Operaciones Unitarias. Facultad de Ingeniería. Grupo de Investigación Ingeniería \\ de Fluidos Complejos y Reología de Alimentos (IFCRA). Universidad de Cartagena. \\ 130015 Cartagena de Indias. Colombia \\ ${ }^{2}$ Departamento de Ingeniería Química. Campus de «El Carmen». Universidad de Huelva. 21071 Huelva. \\ Spain. Campus de Excelencia Internacional Agroalimentario, ceiA3 \\ ${ }^{3}$ Pro ${ }^{2}$ TecS - Chemical Process and Product Technology Research Center. Universidad de Huelva. \\ 21071 Huelva. Spain \\ ${ }^{4}$ Instituto de la Grasa (CSIC). Avda. P. García Tejero, 4. 41012 Sevilla. Spain \\ Corresponding author: franco@uhu.es
}

\section{RESUMEN}

Caracterización química, térmica y viscosa de oleínas ácidas de girasol alto oleico y orujo de oliva y estólidos derivados

Este trabajo presenta la caracterización química, térmica y viscosa de estólidos preparados a partir de oleínas ácidas de girasol alto-oleico y de orujo de oliva, utilizando diferentes métodos catalizados por ácidos y diferentes tiempos de reacción. Se obtuvieron estólidos con pesos moleculares promedios en peso entre 1,7 y 3,4 veces más altos que las oleínas de origen. El peso molecular de los estólidos aumenta cuando se utiliza el método catalizado por ácido sulfúrico y un tiempo de reacción de 3-6 h. Los estólidos obtenidos presentan temperaturas de congelación más altas que las oleínas. En general, los valores de viscosidad están relacionados con el peso molecular del estólido. Se encontraron incrementos significativos de viscosidad en comparación con las oleínas. Los valores máximos de viscosidad se obtuvieron para los estólidos preparados con el método catalizado por ácido sulfúrico. En los estólidos derivados de oleína de orujo de oliva se observaron los mayores incrementos de viscosidad durante las 6 primeras horas de reacción, debido al mayor aumento en el peso molecular. Tiempos más largos de reacción dan lugar a resultados desfavorables. La dependencia de la viscosidad con la temperatura de todos los estólidos es más importante que en las oleínas de partida.

PALABRAS CLAVE: Análisis térmico - Biolubricantes Estólido - Oleínas ácidas de girasol alto oleico - Oleínas ácidas de orujo de oliva - Subproductos - Viscosidad.

\section{SUMMARY}

Chemical, thermal and viscous characterization of high-oleic sunflower and olive pomace acid oils and derived estolides

This work deals with the chemical, thermal and viscous characterization of a variety of estolides, prepared from higholeic sunflower and olive pomace acid oils, using different acid-catalyzed synthesis protocols and reaction times. Estolides with weight-average molecular weights between 1.7 and 3.4 times higher than the original acid oils were obtained. The molecular weight of the estolides was higher when using the sulphuric acid-catalyzed method and a reaction time of 3-6 h. Estolides presented higher freezing temperatures than acid oils. In general, viscosity values are related to estolide molecular weight. Significant increments in viscosities were found in comparison with acid oils. Maximum viscosity values were obtained for estolides prepared using the sulphuric acidcatalyzed method. The largest viscosity increments in olive pomace acid oil-derived estolides were observed during the first 6 hours of reaction, due to an increase in the molecular weight; longer reaction times yielded adverse results. The temperature dependence of viscosity for all estolides studied is significantly larger than for the original acid oils.

KEY-WORDS: Biolubricants - Byproducts - Estolides - High-oleic sunflower acid oil - Olive pomace acid oil Thermal analysis - Viscosity.

\section{INTRODUCTION}

New technologies aimed at the development of products from renewable sources have emerged during the last decade due to increased concerns over the use of petroleum-based products caused by the progressive depletion of the world's reserves of fossil fuels, and also owing to concerns about their environmental impact (Campella et al., 2010). In this regard, vegetable oils constitute a suitable alternative for replacing 'mineral oils', as they are wholly biodegradable, non-toxic, and 'Generally Regarded as Safe' (GRAS) products (Erhan and Pérez, 2002; Erhan and Asadauskas, 2000). Indeed, vegetable oils possess most of the desirable lubricity properties, such as good contact lubrication, high viscosity index (i.e. minimum changes in viscosity with temperature), high flashpoint and low volatility. They are esters of fatty acids and glycerol, and their physicochemical properties rely mainly on the composition of their acyl moieties (Garcés et al., 2011). Vegetable oil basestocks 
can be used to produce acceptable lubricants if they have the proper fatty acid composition and additives.

Soapstock and deodorized distillates are the major by-products from vegetable oil refining. They have little commercial value and are sold at a fraction of the oil cost (Dumont and Narine, 2007). Fatty acids are the major component of soapstock, after water has been extracted. They represent approximately $10 \%$ of the soapstock composition on a wet basis. As fatty acids are mainly used in animal feed, the extraction process must be cheap in order to be justified. Soapstock splitting using a mineral acid is the most common process and the oily phase is sold as acid oil (Woerfel, 1986).

Olive acid oils abound in the Spanish market and are characterized by a high content in unsaponifiables (squalene, sterols, pigments, etc.), especially when recycling waste deodorized oil. The acid oils require rigorous quality control to avoid unwanted mixing with other lipid sources or delivery of a poorly processed product (excess moisture, impurities, elutable material, unsaponifiables and mineral acidity) (de Blas et al., 2003). Little information about direct applications of acid oils has been found. In particular, some modifications of epoxide resins through the synthesis of chlorinated fatty acids and glycidyl ester of fatty acids were proposed from sunflower acid oil (Yazicigil and Ahmetli, 2008).

Estolides are high molecular weight derivatives of fatty acids that have been studied for use in a number of applications, including hydraulic fluid, coatings, cosmetics, lubricants, food emulsifiers, pigments, dispersants and plasticizers (Zerkowski, 2008). Typically, estolides are a class of ester resulting from the reaction between a carboxylic group in a fatty acid molecule and an unsaturation in another fatty acid molecule to form an ester linkage (Isbell et al., 1994, Isbell et al., 2000, Cermak et al., 2001). The number of these linkages determines the structure and properties of estolides. Different molecular parameters (e.g., molecular weight, branching, etc...) and physical properties (e.g. viscosity and density) are obtained by modifying the nature of the base material and reaction conditions. Moreover, these products can improve thermal oxidative stability (Becker et al., 1996, Cermak et al., 2003), and low-temperature properties of vegetable oils (Isbell et al., 1994).

Previous studies have shown that oleic acid, ricinoleic acid and high-oleic sunflower acid oil can be used to obtain estolides with appropriate viscosity and tribological properties, a fact that make them promising compounds for biolubricant applications (García-Zapateiro et al., 2010, 2013).

On the other hand, the use of acid oils as base materials for the synthesis of estolides may have additional benefits, mainly from an environmental point of view. This work deals with the chemical, thermal and viscous characterizations of a variety of estolides, obtained from high-oleic sunflower and olive pomace acid oils, using different synthesis protocols and reaction times. The wide range of viscosities achieved allows these products to be proposed as promising formulations for different lubricant applications.

\section{MATERIAL AND METHODS}

\subsection{Materials}

Acid oils resulting from the refining treatment of high-oleic sunflower and olive pomace oils, supplied by COREYSA (Sevilla, Spain), were used as base materials to obtain the estolides. The chemical composition of these acid oil is shown in Table 1. The quantification of acidity, unsaponifiable matter and fatty acid composition was performed according to the IUPAC Standard Methods.

Highly concentrated sulphuric acid (98\%), highly concentrated perchloric acid (70\%), p-toluenesulfonic acid (PTSA), monobasic and dibasic phosphates, tetrahydrofuran (THF) and sodium sulphate, from Panreac (Spain), were also used to synthesize the estolides.

\subsection{Synthesis of estolides}

Estolides were obtained from high-oleic sunflower acid oil by applying different acidcatalyzed methods described by Isbell et al. (1994). Estolides from the olive pomace acid oil were obtained by following the sulphuric acid-catalyzed method at different reaction times $(3,6,12$ and 24 hours). Scheme 1 illustrates the main chemical reaction promoted and generic chemical structure for the estolide samples studied. Table 2 collects the sample codes of the different estolides studied.

\subsection{Characterization techniques}

The characterization of acid oils and estolides was carried out by means of Fourier transform infrared spectroscopy (FTIR), nuclear magnetic resonance (NMR), gel permeation chromatography (GPC), differential scanning calorimetry (DSC), thermogravimetric analysis (TGA), density and viscosity measurements. At least two replicates of each test were performed on fresh samples.

FTIR spectra were obtained with a Digilab FTS3500ARX (Varian) apparatus. A small drop of sample was placed between two $\mathrm{KBr}$ disks $(32 \times 3 \mathrm{~mm})$ and then the set was placed into an appropriate sample holder. The spectra were obtained in a wavenumber range of $400-4000 \mathrm{~cm}^{-1}$, at $4 \mathrm{~cm}^{-1}$ resolution, in the transmission mode.

${ }^{1} \mathrm{H}-\mathrm{NMR}$ spectra were acquired in a spectrometer Bruker Avance of $11.7 \mathrm{~T}(500 \mathrm{MHz}$ proton resonance). The ${ }^{13} \mathrm{C}-\mathrm{NMR}$ spectra were recorder in a spectrometer Agilent Mercury of $7.04 \mathrm{~T}(300 \mathrm{MHz}$ proton resonance) equipped with an ATB probe and PFG gradients. $\mathrm{CDCl}_{3}$ was used as solvent.

GPC determinations were performed with a Waters apparatus, equipped with two styrage $\AA^{\circledR}$ 
Table 1

Chemical composition of high-oleic sunflower and olive pomace acid oils

\begin{tabular}{ccc}
\hline & $\begin{array}{c}\text { High-oleic sunflower } \\
\text { acid oil }\end{array}$ & $\begin{array}{c}\text { Olive pomace } \\
\text { acid oil }\end{array}$ \\
\hline Acidity (\% oleic acid) & 70.83 & 58.65 \\
Unsaponifiable Matter (\%) & 4.09 & 7.99 \\
Fatty Acid Composition (\%) & 5.31 & \\
$16: 0$ & 0.21 & 14.54 \\
$16: 1$ & 3.36 & 0.89 \\
$18: 0$ & 81.50 & 3.61 \\
$18: 1$ & 6.85 & 65.73 \\
$18: 2$ & - & 11.77 \\
$18: 3$ & 0.64 & 0.98 \\
$20: 0$ & 0.29 & - \\
$20: 1$ & 1.03 & - \\
$22: 0$ & 0.49 & - \\
$24: 0$ & 0.53 & - \\
Others & & 2.48 \\
\hline
\end{tabular}
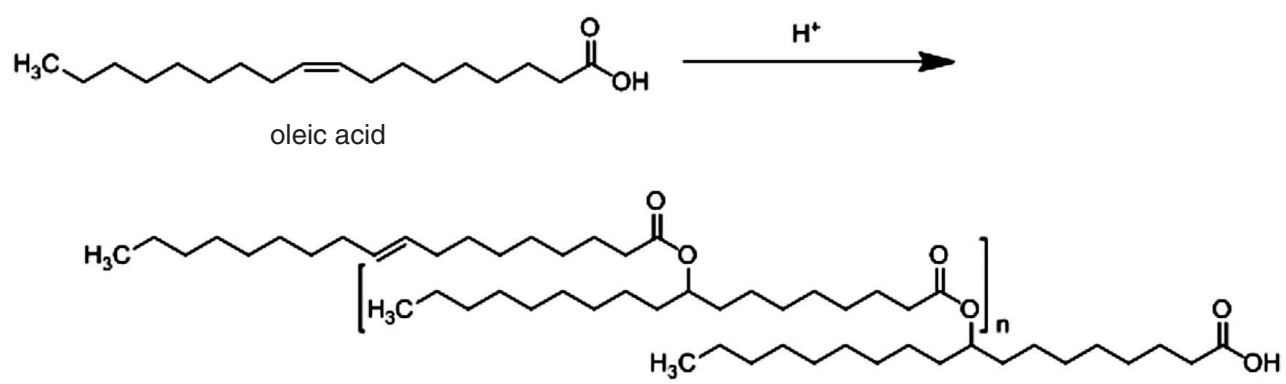

estolide

Scheme1

Synthesis of estolides from oleic acid.

Table 2

Sample codes for the different estolides studied

\begin{tabular}{llcc}
\hline Starting material & \multicolumn{1}{c}{ Acid-catalyzed synthesis method } & Reaction time & Sample code \\
\hline High-oleic sunflower acid oil & Sulphuric acid & 6 & A1 \\
& p-toluenesulfonic acid & 24 & A2 \\
& Perchloric acid & 3 & A3 \\
Olive pomace acid oil & Sulphuric acid & 3 & B1 \\
& Sulphuric acid & 6 & B2 \\
& Sulphuric acid & 12 & B3 \\
& Sulphuric acid & 24 & B4 \\
\hline
\end{tabular}

HR columns $(7.8 \times 300 \mathrm{~mm})$, at $35^{\circ} \mathrm{C}$, using THF $\left(\mathrm{C}_{4} \mathrm{H}_{8} \mathrm{O}\right)$ as eluent. A Waters 2414 refractive index detector and a 1515 isocratic HPLC pump were used. The flow rate was $1.0 \mathrm{~mL} \mathrm{~min}^{-1}$. The numberaverage molecular weight $\left(M_{n}\right)$, the weight-average molecular weight $\left(\mathrm{M}_{\mathrm{w}}\right)$, and polydispersity index
$\left(\mathrm{M}_{\mathrm{w}} / \mathrm{M}_{\mathrm{n}}\right)$ were calculated relative to poly(styrene) standards.

DSC tests were carried out in a TA Instruments calorimeter, model $\mathrm{Q}-100$, under $\mathrm{N}_{2}$ atmosphere, at a flow rate of $50 \mathrm{~mL} \mathrm{~min}^{-1}$, using 10-20 mg samples sealed in hermetic aluminium pans. Heating and 
cooling rates of $5^{\circ} \mathrm{C} \mathrm{min}^{-1}$, in a temperature range of -85 to $120^{\circ} \mathrm{C}$, were applied.

Measurements of mass losses versus temperature were obtained in a TA Instrument thermogravimetric balance, model Q-50, under $\mathrm{N}_{2}$ purge. Typically, 5-10 mg of sample were placed in a platinum pan and heated from $30^{\circ} \mathrm{C}$ to $600^{\circ} \mathrm{C}$, at $10^{\circ} \mathrm{C} \mathrm{min}^{-1}$.

Density determinations were performed in a capillary densimeter, model DMA-5000 (Anton Paar). Dynamic viscosities were measured with a rotational controlled-strain rheometer (ARES, Rheometric Scientific), in a temperature range between 10 and $100^{\circ} \mathrm{C}$. Viscous flow tests were carried out in a shear rate range of 5 to $1000 \mathrm{~s}^{-1}$ using a Couette geometry (inner radius $16 \mathrm{~mm}$, outer radius $17 \mathrm{~mm}$, cylinder length $33.35 \mathrm{~mm}$ ). Kinematic viscosity values, $v$, were then obtained as the ratio of the dynamic viscosity to the density. The viscosity index (VI) was also estimated according to the ASTM D-2270 standard, at $40^{\circ} \mathrm{C}$ and $100^{\circ} \mathrm{C}$.

\section{RESULTS AND DISCUSSION}

\subsection{Chemical characterization of acid oils and derived estolides}

Table 1 shows the main groups of chemical components of two acid oil samples used in these assays. As can be observed, the free fatty acid (FFA) content is above $70 \%$ and $58 \%$ for high-oleic sunflower (HOSOL) and olive pomace (OPOL) acid oils, respectively. Saturated fatty acids were $10 \%$ higher in OPOL. Palmitic acid $\left(\mathrm{C}_{16: 0}\right)$ was the most abundant saturated fatty acid whereas oleic acid $\left(\mathrm{C}_{18: 1}\right)$ was found to be the predominant fatty acid present in both types of acid oils. Finally, a relatively high content of linoleic acid $\left(\mathrm{C}_{18: 2}\right)$ was also found in both samples. On the other hand, unsaponifiable matter was $4.09 \%$ for HOSOL, practically half the OPOL content in these compounds. This fraction is composed of a variety of minor components of different polarity, such as hydrocarbons, fatty alcohols and sterols. These compositions and the previous experience with high-oleic sunflower acid oil (García-Zapateiro et al., 2010), make these byproducts feasible raw materials for the lubricant industry. In this sense, it should be mentioned that little information about direct applications of acid oils in this field has been found.

FTIR spectroscopy is an appropriate and sensitive technique to monitor the synthesis of estolides (Erhan et al., 1996). Figures 1a and 1b show the FTIR spectra of estolides obtained from HOSOL and OPOL, respectively, using different acid-catalyzed methods and reaction times. These materials are mixtures of unreacted fatty acids, estolides and some other undesired derived products. Triglycerides and free fatty acids are the principal components in acid oils and, consequently, they dominate the spectra. The acid oils spectra

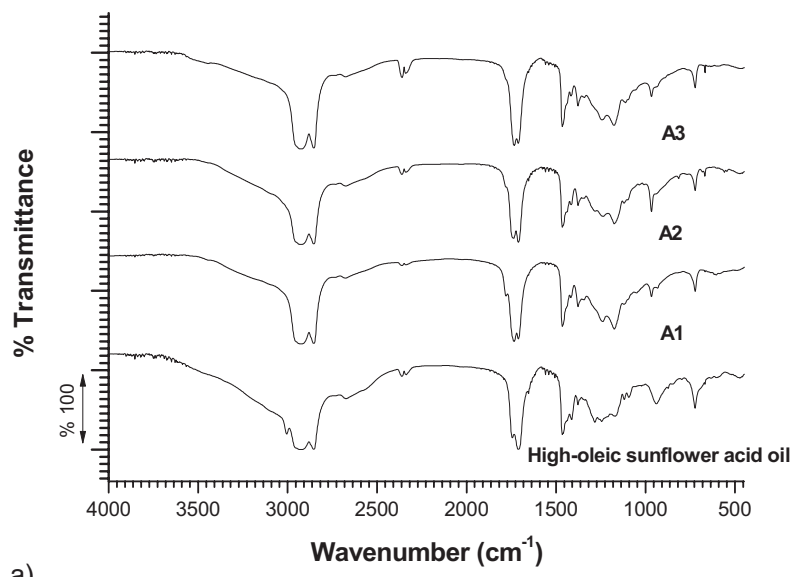

a)

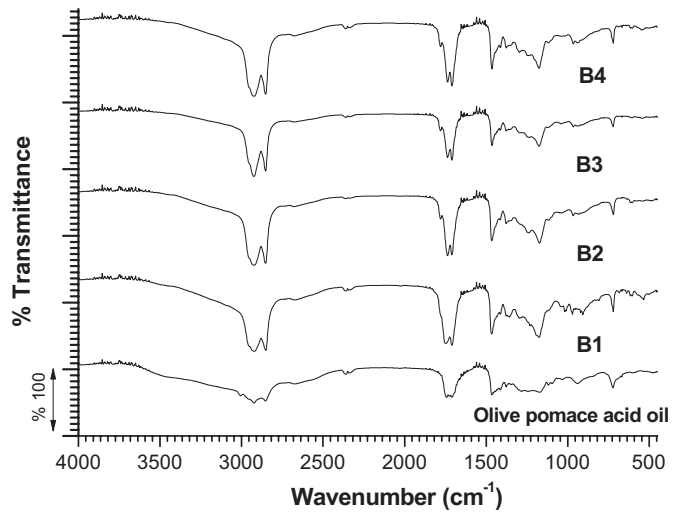

b)

Figure 1

FTIR spectra of a) high-oleic sunflower acid oil and derived estolides and b) olive pomace acid oil and derived estolides.

showed the typical characteristic absorption bands associated with common oils. Thus, the absorption band at around $3550 \mathrm{~cm}^{-1}$ is due to the $\mathrm{OH}$ stretching vibration mode of mono or diglycerides or water in acid oil samples (van de Voort et al., 1994), the band at $3005 \mathrm{~cm}^{-1}$ has been assigned to the $=\mathrm{CH}$ cis stretching vibration (Guillen and Cabo, 1997) and triglyceride ester carbonyl group gives an absorption band at around $1744 \mathrm{~cm}^{-1}$. A typical $\mathrm{C}=\mathrm{O}$ absorption of free fatty acids is found at around $1712 \mathrm{~cm}^{-1}$. Regarding the FTIR characterization of estolides, the transmittance band corresponding to the estolide carbonyl group always appears in the range of $1732-1737 \mathrm{~cm}^{-1}$, together with the carboxylic band at around 1711$1712 \mathrm{~cm}^{-1}$, which otherwise appears in the acid oils FTIR spectra. A higher intensity of the estolide carbonyl band relative to the carboxylic band, attributed to a higher proportion of estolide ester linkages, can be appreciated in the FTIR spectra of estolides synthesized from HOSOL, using the sulphuric and perchloric acid methods (A1 and A3 samples) (Figure 1a) and when estolides from OPOL were synthesized by applying a reaction time of $6 \mathrm{~h}$. Moreover, the peak at 3005, assigned to the $=\mathrm{CH}$ cis stretching vibration, almost disappears in the estolides FTIR spectra.

${ }^{1} \mathrm{H}-\mathrm{NMR}$ spectra were also obtained to confirm the estolide chemical structures. The H-NMR spectra 
for the different estolide samples studied were rather similar. $A{ }^{1} \mathrm{H}-\mathrm{NMR}$ spectrum for a selected estolide sample (B3) is shown in Figure 2. As can be observed, these materials consist of mixtures of estolides and some other products derived from acid oils. The main signals of this spectrum are in agreement with the chemical structure of estolides proposed in previous studies (Isbell and Kleiman, 1994). The key signal of this spectrum is the one corresponding to estolide methine at $4.84 \mathrm{ppm}$, which confirms the formation of the ester linkage. In addition to the estolide methine signal, the other main characteristic feature for the estolide moiety is the $\alpha$-carboxylic protons. The $\alpha$-methylene protons adjacent to the acid group appear at $2.52 \mathrm{ppm}$, whereas the $\alpha$-methylene protons adjacent to the ester group are up-field (2.34 ppm). Besides this, olefinic protons, $-\mathrm{CH}=\mathrm{CH}$-, present in the chemical structure (see scheme 1) resonate at $5.37 \mathrm{ppm}$. Finally, the protons of residual triglycerides from acid oils can be detected at 3.66-4.47 ppm (Vlahov, 1999). The main feature of the ${ }^{13} \mathrm{C}-\mathrm{NMR}$ estolide spectra is the methine carbon at 74.0 ppm., also providing evidence of estolide formation. Moreover, the two different carbonyl carbons resonating at $179.4 \mathrm{ppm}$ (acid) and $173.7 \mathrm{ppm}$ (ester), respectively, were detected.

The molecular weights of acid oils and estolides were determined by GPC. Table 3 presents the weight- $\left(M_{w}\right)$ and number-average $\left(M_{n}\right)$ molecular weights, and polydispersity indexes for these materials. A certain degree of polymerization has been detected in the initial acid oil samples, which show two peaks in the GPC chromatogram, one corresponding to the mixture of triglycerides and free fatty acids (around $500 \mathrm{~g} / \mathrm{mol}$ for HOSOL and 600 for OPOL, as expected) and another one corresponding to a fraction of higher molecular weight (around $1270 \mathrm{~g} \mathrm{~mol}^{-1}$ for HOSOL and 1400 for OPOL) (Table 3). Estolide molecular weight depends on the acid-catalyzed method employed and reaction time. As can be observed, the highest

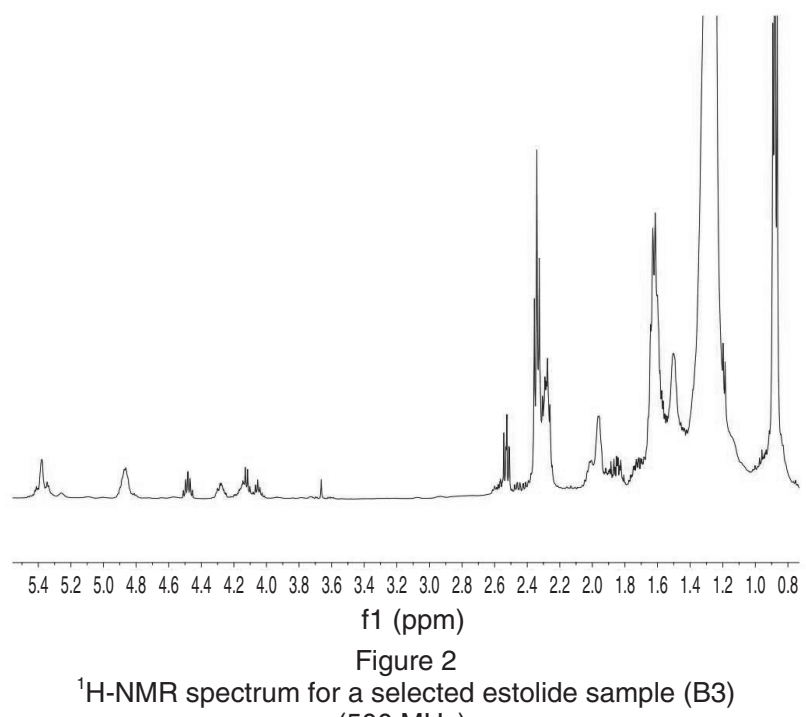

$(500 \mathrm{MHz})$.

molecular weight for HOSOL-derived estolides was obtained using the sulphuric acid-catalyzed method. With the aiming of establishing the optimum reaction time for estolide synthesis using olive pomace acid oil and the sulphuric acid-catalyzed method, different reaction times were monitored, 3, 6, 12 and $24 \mathrm{~h}$. For all estolide samples, the peak corresponding to the non-polymerized fraction still appears. However, a significant increase in molecular weight was observed after $3 \mathrm{~h}$. Further increments were noticed after $6 \mathrm{~h}$ of reaction. On the contrary, a slight decrease in molecular weight was obtained after 12 $\mathrm{h}$ and subsequently after $24 \mathrm{~h}$. In general, estolides with weight-average molecular weights between 1.7 and 3.4 times higher than the original acid oils were obtained. Similar influence of the reaction time was found in a preliminary study performed with HOSOL-derived estolides (Garcia-Zapateiro et al., 2010). Moreover, estolides obtained from OPOL displayed a slightly higher degree of polidispersity than HOSOL-derived estolides.

Table 3

Molecular weight parameters for acid oils and derived estolides studied

\begin{tabular}{ccccccc}
\hline \multirow{2}{*}{ Sample code } & \multicolumn{2}{c}{$\begin{array}{c}\mathbf{M}_{\mathbf{w}} \\
\left(\mathbf{g} \mathbf{~ m o l}^{-1}\right)\end{array}$} & \multicolumn{2}{c}{$\begin{array}{c}\mathbf{M}_{\mathbf{n}} \\
(\mathbf{g} \text { mol }\end{array}$} & \multicolumn{2}{c}{$\mathbf{M}_{\mathbf{w}} / \mathbf{M}_{\mathbf{n}}$} \\
\cline { 2 - 7 } & Peak 1 & Peak 2 & Peak 1 & Peak 2 & Peak 1 & Peak 2 \\
\hline High-oleic sunflower acid oil & 1270 & 510 & 1230 & 510 & 1.03 & 1.00 \\
A1 & 4300 & 515 & 3310 & 514 & 1.30 & 1.00 \\
A2 & 2539 & 578 & 2175 & 571 & 1.16 & 1.01 \\
A3 & 2188 & 572 & 2000 & 565 & 1.09 & 1.01 \\
Olive pomace acid oil & 1397 & 619 & 1316 & 603 & 1.06 & 1.02 \\
B1 & 2660 & 649 & 1990 & 628 & 1.33 & 1.03 \\
B2 & 2880 & 629 & 1965 & 614 & 1.46 & 1.02 \\
B3 & 2614 & 615 & 1854 & 602 & 1.41 & 1.02 \\
B4 & 2505 & 599 & 1724 & 588 & 1.45 & 1.01 \\
\hline
\end{tabular}




\subsection{Thermal characterization of acid oils and derived estolides}

Thermal degradation was studied by means of a thermogravimetric analysis (TGA). Figures $3 a$ and $3 b$ show TGA curves in the form of a weight loss derivative function for estolides from high-oleic sunflower and olive pomace acid oils, respectively. Table 4 gathers the main characteristic parameters derived from this thermal analysis, estimated as indicated elsewhere (Sánchez et al., 2009). As can be observed, the thermal decomposition of acid oils occurs in two stages (DTG maximum peaks at $257^{\circ} \mathrm{C}$ and $400^{\circ} \mathrm{C}$ for $\mathrm{HOSOL}$ and $284^{\circ} \mathrm{C}$ and $429^{\circ} \mathrm{C}$ for OPOL). Thus, the first peak of acid oils appears at temperatures similar to that found for the oleic acid decomposition (García-Zapateiro et al., 2013), although it is slightly higher for OPOL. The other decomposition stage starts at around $350^{\circ} \mathrm{C}$, with temperatures for the maximum decomposition rate at $400^{\circ} \mathrm{C}$ and $429^{\circ} \mathrm{C}$, respectively. Estolides derived from these acid oils show three main peaks, attributed to different stages of the decomposition process and polymerization degrees, corroborating that estolide samples are complex mixtures of different compounds (see Table 4). The highest amounts of residues were obtained for OPOL and estolides prepared from HOSOL using the p-toluenesulfonic acid method.

Vegetable oil-based lubricants have good lubricity and biodegradability but often offer poor low temperature performance. These lubricant low temperature properties are traditionally evaluated by means of pour point determinations, the minimum temperature at which a liquid will pour (Isbell et al., 2001 and Govindapillai et al., 2009). Differential scanning calorimetry (DSC) has been successfully used to assess the crystallization behavior of vegetable oils and their blends with pour point depressant additives, by analyzing the exothermic change associated with this process (Jiang et al., 2001, Quinchia et al., 2012). Figures $4 \mathrm{a}$ and $4 \mathrm{~b}$ display the DSC cooling curves obtained during a downward temperature sweep test, for the estolides obtained from high-oleic sunflower and olive pomace acid oils, respectively. Table 5 summarizes the most relevant onset and maximum temperatures resulting from the analysis of these curves. The cooling thermogram of HOSOL exhibits three main peaks (at around $-1^{\circ} \mathrm{C},-10^{\circ} \mathrm{C}$ and $-30^{\circ} \mathrm{C}$ ). As previously reported (Suzuki et al., 1985, Morselli-Ribeiro et al., 2012, García-Zapaterio et al., 2013), peaks at $-1{ }^{\circ} \mathrm{C}$ and $-10^{\circ} \mathrm{C}$ are characteristics of oleic acid, which are associated with the crystallization of the meta-stable $\alpha$ form and the polymorphic transformation from $\alpha$ to $\gamma$ forms, respectively. The crystallization peak at a lower temperature (around $-30^{\circ} \mathrm{C}$ ) can be attributed to the crystallization of more unsaturated fatty acids, like the linoleic acid, as well as remaining fractions of di- and triglycerides of the high-oleic sunflower oil (Hagemann, 1988, Quinchia et al., 2012). In the case of estolides obtained from HOSOL, using the three acid-catalyzed methods, the first freezing point is found at higher temperatures than for acid oils, which means poorer performance at low temperature. In this sense, apart from the increment of molecular weight, a reduction in the number of unsaturations in the hydrocarbon chain favors packing into crystalline forms, hence showing higher freezing temperatures (Govindapillai et al., 2009; Mutlu et al., 2010. The highest $\mathrm{T}_{\text {onset }}$ values were obtained using the perchloric and p-toluenesulfonic acid methods. Besides this, wide exothermic peaks at lower temperatures were detected for all HOSOL-derived estolides. On the other hand, two main peaks (at around $0^{\circ} \mathrm{C}$ and $-23^{\circ} \mathrm{C}$ ) were detected for OPOL. Concerning OPOL composition and the lower acidity found for this acid oil (Table 1), the peak at $0^{\circ} \mathrm{C}$ can be assigned to the crystallization of the oleic acid meta-stable $\alpha$ form and, maybe, the corresponding monoolein (Vereecken et al., 2009), whereas the main peak at $-23^{\circ} \mathrm{C}$ can be attributed to both the crystallization of free linoleic acid, which appears in a higher amount in this acid oil, and some fractions
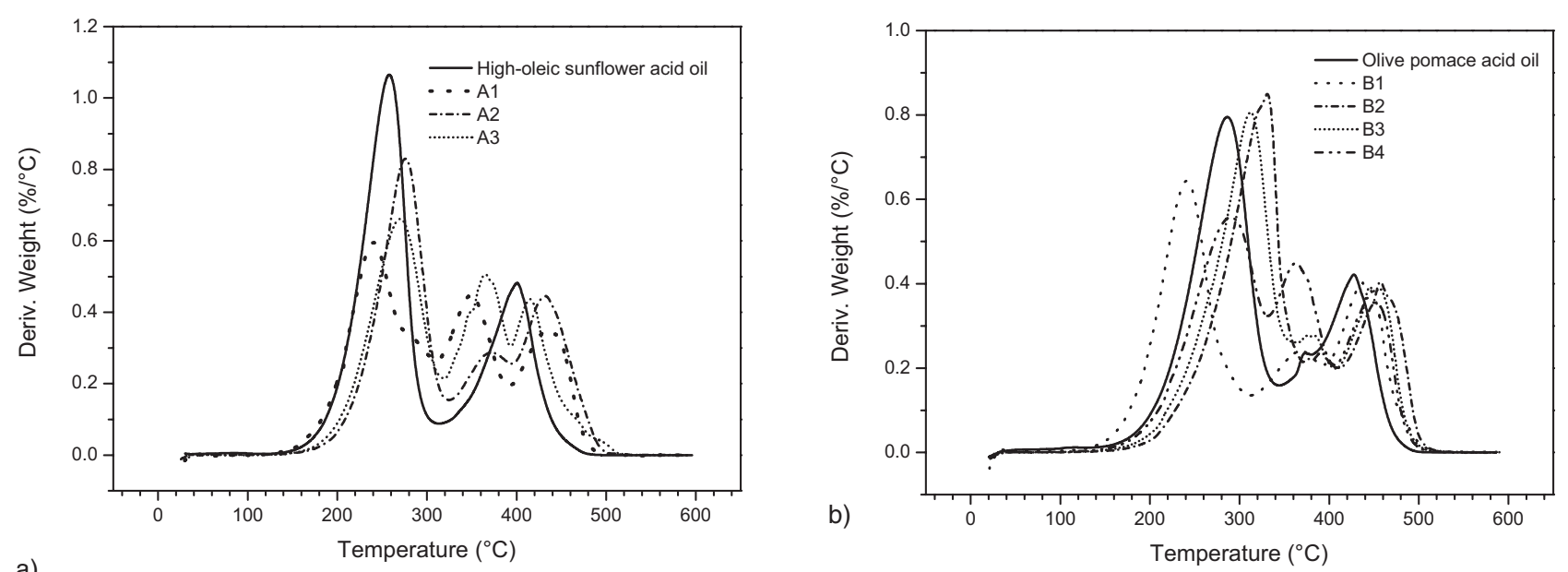

Figure 3

TGA thermograms for a) high oleic sunflower acid oil and derived estolides and b) olive pomace acid oil and derived estolides. 
Table 4

Decomposition temperatures and residue, from TGA measurements, for acid oils and derived estolides studied

\begin{tabular}{|c|c|c|c|c|c|}
\hline SAMPLE & DTG peaks & $\mathrm{T}_{\text {onset }}\left({ }^{\circ} \mathrm{C}\right)$ & Decomposition range & $\mathrm{T}_{\max }\left({ }^{\circ} \mathrm{C}\right)$ & Residue (\%) \\
\hline \multirow[t]{2}{*}{ High-oleic sunflower acid oil } & Peak 1 & 201 & $201-307$ & 257 & 1.82 \\
\hline & Peak 2 & 344 & $344-478$ & 400 & \\
\hline \multirow[t]{3}{*}{$\mathrm{A} 1$} & Peak 1 & 198 & $198-306$ & 239 & 2.63 \\
\hline & Peak 2 & 317 & $317-388$ & 351 & \\
\hline & Peak 3 & 397 & $397-492$ & 439 & \\
\hline \multirow[t]{3}{*}{$\mathrm{A} 2$} & Peak 1 & 222 & $222-323$ & 275 & 3.03 \\
\hline & Peak 2 & 335 & $335-395$ & 356 & \\
\hline & Peak 3 & 401 & $401-501$ & 434 & \\
\hline \multirow[t]{3}{*}{ A3 } & Peak 1 & 210 & $210-317$ & 269 & 1.03 \\
\hline & Peak 2 & 338 & 338-393 & 364 & \\
\hline & Peak 3 & 395 & $395-479$ & 416 & \\
\hline \multirow[t]{2}{*}{ Olive pomace acid oil } & Peak 1 & 214 & 214-340 & 284 & 3.15 \\
\hline & Peak 2 & 360 & $360-498$ & 429 & \\
\hline \multirow[t]{3}{*}{ B1 } & Peak 1 & 182 & $182-307$ & 239 & 1.47 \\
\hline & Peak 2 & 324 & $324-390$ & 359 & \\
\hline & Peak 3 & 404 & $404-513$ & 449 & \\
\hline \multirow[t]{3}{*}{ B2 } & Peak 1 & 249 & $249-372$ & 330 & 2.35 \\
\hline & Peak 2 & 383 & $383-404$ & 392 & \\
\hline & Peak 3 & 430 & $430-518$ & 470 & \\
\hline \multirow[t]{3}{*}{ B3 } & Peak 1 & 243 & 243-352 & 309 & 2.38 \\
\hline & Peak 2 & 367 & $367-405$ & 386 & \\
\hline & Peak 3 & 423 & $423-516$ & 459 & \\
\hline \multirow[t]{3}{*}{ B4 } & Peak 1 & 209 & $209-330$ & 278 & 2.99 \\
\hline & Peak 2 & 337 & $337-406$ & 367 & \\
\hline & Peak 3 & 412 & $412-513$ & 459 & \\
\hline
\end{tabular}

of di- and triglycerides. All estolides obtained from OPOL exhibited one single but wide exothermic peak, indicating different coexisting structures and polymerization degrees. Again, as a consequence of the polymerization degree and reduction in the number of unsaturations, the freezing point was always found at higher temperatures than the first peak for OPOL. The estolide sample prepared from OPOL, using a reaction time of $3 \mathrm{~h}$, showed a higher freezing temperature. In general, $T_{\text {onset }}$ seems to be influenced by the estolide polydispersity index (see Table 3). The lower the polidispersity index, the higher freezing temperature is.

\subsection{Viscous characterization of acid oils and derived estolides}

Table 6 shows densities, and dynamic and kinematic viscosities at different temperatures $\left(10-100^{\circ} \mathrm{C}\right)$, for HOSOL and derived estolides obtained using different acid-catalyed methods. As can be observed, viscosity values largely depend on the acid-catalyzed method employed. Thus, estolides obtained using the sulphuric acidcatalyed method present much higher viscosities than those prepared using the p-toluenesulfonic or perchloric acid methods. In general, viscosity values are related to the estolide molecular weight (see Table 3).

Table 7 shows the above mentioned physical properties for OPOL and derived estolides obtained after different reaction times. As can be seen, increments in kinematic viscosities of up to around $443 \%$ and $235 \%$ at $40^{\circ} \mathrm{C}$ and $100^{\circ} \mathrm{C}$, respectively, in relation to the original acid oil viscosity values, were obtained after a reaction time of $3 \mathrm{~h}$. However, the maximum viscosity values were obtained after reaction times of up to $6 \mathrm{~h}$, coinciding with 


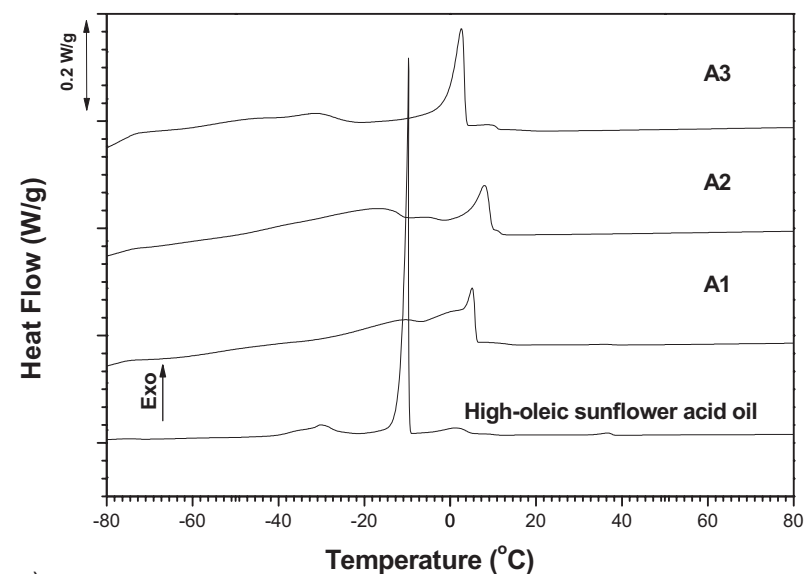

a)

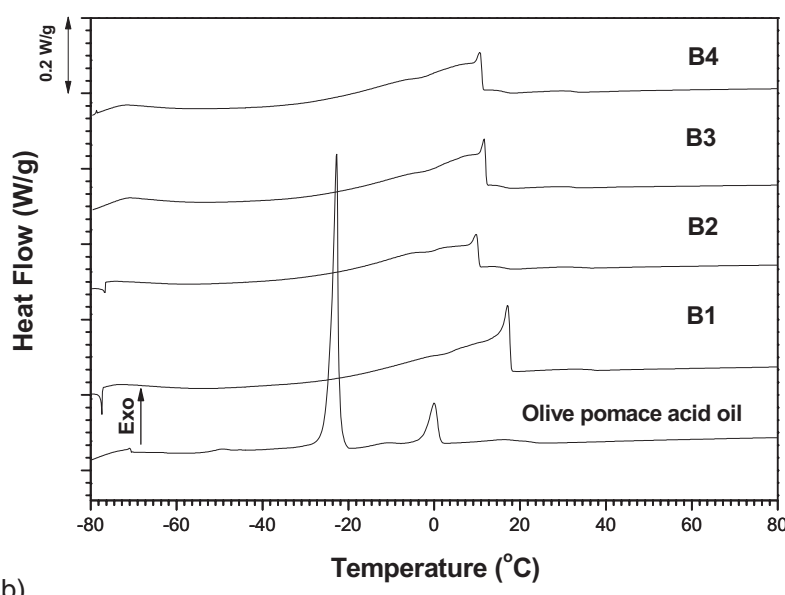

Figure 4

DSC curves for a) high oleic sunflower acid oil and derived estolides and b) olive pomace acid oil and derived estolides.

the maximum estolide molecular weight. On the contrary, estolide viscosities significantly decrease after $6 \mathrm{~h}$ reaction time, related to a decrease in the average molecular weight. An extremely high viscosity value at $25^{\circ} \mathrm{C}$ was obtained for the estolide processed for $3 \mathrm{~h}$, which can be explained by considering the extremely high crystallization temperature exhibited (see Table 5). In fact, this sample became completely solid at $10^{\circ} \mathrm{C}$. On the other hand, HOSOL-derived estolide prepared using the sulphuric acid-catalyzed methods exhibits, in general, lower viscosities than the OPOL-derived estolide prepared for $6 \mathrm{~h}$, and similar to those found for the estolide obtained after $12 \mathrm{~h}$ reaction time.

The viscosity index (VI) is usually calculated to evaluate the viscosity-temperature dependence of lubricating oils. VI is estimated from the kinematic viscosity values at $40^{\circ} \mathrm{C}$ and $100^{\circ} \mathrm{C}$, according to the ASTM D2270 standard. Table 8 shows the values of VI for the two acid oils studied and for the estolides prepared using different acid-catalyzed methods and reaction times. The two acid oils present similar VI. HOSOLderived estolides show lower VI, especially those prepared using the sulphuric and p-toluenesulfonic acid-catalyzed methods, thus yielding a higher
Table 5

Characteristic crystallization temperatures, from DSC cooling curves, for acid oils and derived estolides samples studied

\begin{tabular}{crrr}
\hline SAMPLE & Peak & $\mathbf{T}_{\text {onset }}\left({ }^{\circ} \mathbf{C}\right)$ & $\mathbf{T}_{\max }\left({ }^{\circ} \mathbf{C}\right)$ \\
\hline $\begin{array}{c}\text { High-oleic } \\
\text { ounflower acid }\end{array}$ & Peak 1 & 4.84 & -1.30 \\
A1 & Peak 2 & -9.46 & -9.69 \\
A2 & Peak 3 & -25.61 & -30.26 \\
& Peak 1 & 6.09 & 5.13 \\
& Peak 2 & 11.81 & 11.08 \\
A3 & Peak 3 & -10.60 & -18.52 \\
& Peak 1 & 11.12 & 9.44 \\
& Peak 2 & 3.67 & 2.66 \\
Olive pomace & Peak 3 & -23.84 & -31.15 \\
acid oil & Peak 1 & 1.36 & -0.04 \\
B1 & Peak 2 & -22.23 & -22.67 \\
B2 & Peak 1 & 17.87 & 17.04 \\
B3 & Peak 1 & 10.57 & 9.71 \\
B4 & Peak 1 & 11.36 & 10.58 \\
\hline
\end{tabular}

temperature dependence of viscosity. On the other hand, OPOL-derived estolides do not show a significant change in $\mathrm{VI}$, except for that obtained after a reaction time of $3 \mathrm{~h}$, which shows a significantly reduced $\mathrm{VI}$ value. As is well known, $\mathrm{VI}$ is estimated from the kinematic viscosities only at two temperatures, 40 and $100^{\circ} \mathrm{C}$. Similar but more accurate information can be deduced from the analysis of the activation energies obtained from the fitting of the experimental dynamic viscosity data at different temperatures to an Arrhenius type equation, as previously reported (Quinchia et al., 2010):

$$
\eta=A e^{\frac{E a}{R T}}
$$

where $\eta$ is the dynamic viscosity, $A$ is the preexponential factor, $E_{a}$ is the activation energy, $R$ is the gas constant $\left(8.314 \mathrm{~J} \cdot \mathrm{mol}^{-1} \cdot \mathrm{K}^{-1}\right)$, and $\mathrm{T}$ is the temperature $(\mathrm{K})$. Figure 5 shows the evolution of the apparent viscosity with temperature for the series of OPOL-derived estolides synthesized, using the sulphuric acid-catalyzed method, after different reaction times, in a temperature range comprised between 25 and $100^{\circ} \mathrm{C}$. Apparent viscosity values at $10^{\circ} \mathrm{C}$ deviate from the Arrhenius tendency due to the incipient crystallization process (see Table 5) and, therefore, there were not taken into account for Arrhenius' fitting. $E_{a}$ values are collected in Table 8 for all the samples studied. As can be observed, 
Table 6

Densities $(\rho)$, dynamic $(\eta)$ and kinematic viscosities $(v)$, and relative increment in kinematic viscosity $(\Delta v)$, at different temperatures $\left(10-100^{\circ} \mathrm{C}\right)$, for high-oleic sunflower acid oil and derived estolides synthesized with different acid-catalyzed methods

\begin{tabular}{|c|c|c|c|c|c|}
\hline Samples & $\mathrm{T}\left({ }^{\circ} \mathrm{C}\right)$ & $\rho\left(\mathrm{g} \mathrm{cm}^{-3}\right)^{\mathrm{a}}$ & $\eta$ (mPa.s) $^{b}$ & $v\left(\mathrm{~mm}^{2} \mathrm{~s}^{-1}\right)$ & $\% \Delta v$ \\
\hline \multirow{5}{*}{$\begin{array}{l}\text { High-oleic sunflower } \\
\text { acid oil }\end{array}$} & 10 & 0.9241 & 277.0 & 299.8 & \\
\hline & 25 & 0.9137 & 62.8 & 68.7 & \\
\hline & 40 & 0.9027 & 30.6 & 33.9 & \\
\hline & 70 & 0.8810 & 11.9 & 13.5 & \\
\hline & 100 & 0.8599 & 6.4 & 7.4 & \\
\hline \multirow[t]{5}{*}{$\mathrm{A} 1$} & 10 & 0.9656 & 6675.1 & 6912.9 & 2206.2 \\
\hline & 25 & 0.9527 & 1337.0 & 1403.4 & 1941.8 \\
\hline & 40 & 0.9416 & 400.5 & 425.3 & 1154.8 \\
\hline & 70 & 0.9218 & 96.8 & 105.0 & 677.4 \\
\hline & 100 & 0.9024 & 38.5 & 42.7 & 473.2 \\
\hline \multirow[t]{5}{*}{$\mathrm{A} 2$} & 10 & 0.9470 & 4916.3 & 5191.4 & 1631.9 \\
\hline & 25 & 0.9292 & 366.0 & 393.9 & 473.1 \\
\hline & 40 & 0.9180 & 110.6 & 120.5 & 255.4 \\
\hline & 70 & 0.8978 & 39.7 & 44.2 & 227.4 \\
\hline & 100 & 0.8779 & 16.7 & 19.0 & 155.6 \\
\hline \multirow[t]{5}{*}{ A3 } & 10 & 0.9387 & 2165.0 & 2306.4 & 669.4 \\
\hline & 25 & 0.9246 & 292.1 & 315.9 & 359.6 \\
\hline & 40 & 0.9142 & 93.6 & 102.4 & 202.0 \\
\hline & 70 & 0.8942 & 32.5 & 36.3 & 169.1 \\
\hline & 100 & 0.8741 & 15.0 & 17.2 & 130.6 \\
\hline
\end{tabular}

${ }^{a, b}$ standard deviation for density and dynamic viscosity measurements was always lower than $10^{-4}$.

the viscosity-temperature dependence, expressed in the form of activation energy, $E_{a}$, is reasonably in agreement with the VI values previously discussed. OPOL-derived estolides show similar $E_{a}$ values among them, and are also very similar to those found in HOSOL-derived estolides prepared using the perchloric and p-toluenesulfonic acidcatalyzed methods, but lower than that exhibited by the HOSOL-derived estolide obtained with the sulphuric method.

\section{CONCLUSIONS}

Estolides derived from high-oleic sunflower and olive pomace acid oils with a wide range of viscosities have been obtained. The use of these acid oils as base materials for the synthesis of estolides may have additional benefits, mainly from an environmental point of view. Regarding the lowtemperature thermal behavior, estolides displayed higher freezing temperatures than acid oils. OPOL-derived estolides present higher freezing temperatures than estolides obtained from HOSOL. HOSOL-derived estolides obtained using the sulphuric method showed higher viscosity values than those obtained using the p-toluenesulfonic and perchloric methods, as a consequence of their higher molecular weight. The reaction

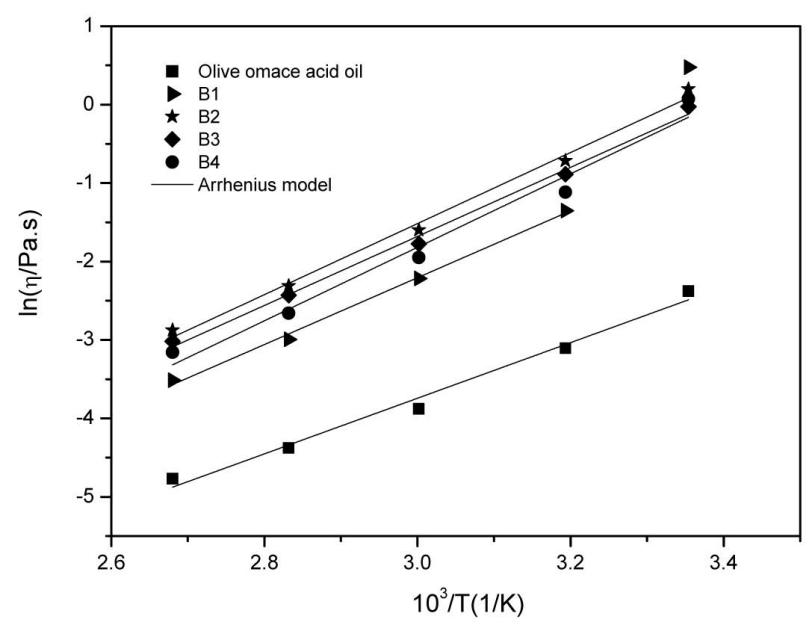

Figure 5

Evolution of the dynamic viscosity with temperature for olive pomace acid oil and derived estolides and fitting to the Arrhenius model. 
Table 7

Densities $(\rho)$, dynamic $(\eta)$ and kinematic viscosities $(v)$, and relative increment in kinematic viscosity $(\Delta v)$, at different temperatures $\left(10-100^{\circ} \mathrm{C}\right)$, for olive pomace acid oil and derived estolides synthesized by applying different reaction times

\begin{tabular}{|c|c|c|c|c|c|}
\hline Samples & $\mathrm{T}\left({ }^{\circ} \mathrm{C}\right)$ & $\rho\left(\mathrm{g} \mathrm{cm}^{-3}\right)^{\mathrm{a}}$ & $\eta(\mathrm{mPa} . \mathbf{s})^{\mathrm{b}}$ & $v\left(\mathrm{~mm}^{2} \mathrm{~s}^{-1)}\right.$ & $\% \Delta v$ \\
\hline \multirow[t]{6}{*}{ Olive pomace acid oil } & 10 & 0.9245 & 411.5 & 445.1 & \\
\hline & 25 & 0.9077 & 92.6 & 102.0 & \\
\hline & 40 & 0.8955 & 44.8 & 50.0 & \\
\hline & 60 & 0.8808 & 20.7 & 23.5 & \\
\hline & 80 & 0.8669 & 12.6 & 14.5 & \\
\hline & 100 & 0.8530 & 8.5 & 10.0 & \\
\hline \multirow[t]{6}{*}{ B1 } & 10 & - & - & - & \\
\hline & 25 & 0.9664 & 1604.0 & 1659.8 & 1527.0 \\
\hline & 40 & 0.9514 & 258.6 & 271.8 & 443.3 \\
\hline & 60 & 0.9402 & 109.0 & 115.9 & 393.3 \\
\hline & 80 & 0.9274 & 50.2 & 54.1 & 272.4 \\
\hline & 100 & 0.9147 & 30.6 & 33.5 & 235.7 \\
\hline \multirow[t]{6}{*}{ B2 } & 10 & 0.9657 & 5054.0 & 5233.5 & 1075.8 \\
\hline & 25 & 0.9576 & 1215.1 & 1268.9 & 1143.8 \\
\hline & 40 & 0.9414 & 488.2 & 518.6 & 936.6 \\
\hline & 60 & 0.9285 & 201.5 & 217.0 & 823.4 \\
\hline & 80 & 0.9285 & 99.1 & 106.7 & 634.3 \\
\hline & 100 & 0.8915 & 53.7 & 60.2 & 504.5 \\
\hline \multirow[t]{6}{*}{ B3 } & 10 & 0.9570 & 2927.9 & 3059.5 & 587.4 \\
\hline & 25 & 0.9466 & 973.3 & 1028.2 & 907.9 \\
\hline & 40 & 0.9352 & 411.2 & 439.7 & 778.9 \\
\hline & 60 & 0.9223 & 169.5 & 183.8 & 682.0 \\
\hline & 80 & 0.9093 & 88.1 & 96.9 & 566.6 \\
\hline & 100 & 0.8964 & 48.0 & 53.5 & 437.4 \\
\hline \multirow[t]{6}{*}{ B4 } & 10 & 0.9625 & 3023.8 & 3141.6 & 605.8 \\
\hline & 25 & 0.9474 & 1072.2 & 1131.7 & 1009.4 \\
\hline & 40 & 0.9342 & 327.3 & 350.4 & 600.3 \\
\hline & 60 & 0.9210 & 142.4 & 154.6 & 557.9 \\
\hline & 80 & 0.9080 & 70.1 & 77.2 & 431.2 \\
\hline & 100 & 0.8952 & 40.3 & 45.0 & 351.8 \\
\hline
\end{tabular}

${ }^{a, b}$ Standard deviation for density and dynamic viscosity measurements was always lower than $10^{-4}$.

time in the synthesis of OPOL-derived estolides affects the average-weight molecular weight and, consequently, the kinematic viscosities of estolides. Thus, a significant increase in molecular weight was observed after $3 \mathrm{~h}$ of reaction. Nevertheless, the maximum viscosities were generally obtained for reaction times of $6 \mathrm{~h}$, coinciding with the highest molecular weight. Even higher viscosity values were found in the HOSOL-derived estolide sample obtained using the sulphuric acid-catalyzed method. The temperature dependence of viscosity for all estolides studied is significantly greater than for the original acid oils.

\section{ACKNOWLEDGEMENTS}

This work is part of a research project (CTQ2010-15338) sponsored by a MINECOFEDER programme (70\% European cofunding rate). The authors gratefully acknowledge its financial support. 
Table 8

Viscosity indexes and activation energies for acid oils and derived estolides studied

\begin{tabular}{cccc}
\hline Sample & $\begin{array}{c}\text { Activation energy } \\
\text { (KJ/mol) }\end{array}$ & $\mathbf{R}^{2}$ & $\begin{array}{c}\text { Viscosity index } \\
\text { (VI) }\end{array}$ \\
\hline High-oleic sunflower acid oil & 29.1 & 0.990 & 194 \\
A1 & 40.5 & 0.979 & 153 \\
A2 & 38.2 & 0.979 & 179 \\
A3 & 36.7 & 0.965 & 185 \\
Olive pomace acid oil & 28.4 & 0.987 & 191 \\
B1 & 36.2 & 0.990 & 168 \\
B2 & 37.2 & 0.995 & 187 \\
B3 & 36.3 & 0.996 & 188 \\
B4 & 37.5 & 0.979 & 187 \\
\hline
\end{tabular}

\section{REFERENCES}

Becker R, Knorr A. 1996. An evaluation of antioxidants for vegetable oils at elevated temperatures. Lubr. Sci. 8, 95-117.

Campella A, Rustoy E, Baldessari A, Baltanás MA. 2010. Lubricants from chemically modified vegetable oils. Bioresource Technol. 101, 245-254.

Cermak SC, Isbell TA. 2001. Synthesis of estolides from oleic and saturated fatty acids. J. Am. Oil Chem. Soc. 78, 557-565.

Cermak SC, Isbell TA. 2003. Improved oxidative stability of estolide esters. Ind. Crops Prod. 18, 223-230.

De Blas C, Mateos GG, Rebollar PG. 2003. Composición y valor nutritivo de alimentos para la formulación de piensos compuestos ( $2^{\mathrm{a}}$ ed.) Madrid, España. p 423.

Dumont MJ, Narine SS. 2007. Soapstock and deodorizer distillates from North American vegetable oils: Review on their characterization, extraction and utilization. Food Res. Int. 40, 957-974.

Erhan SM, Robert PA, Thomas PA. 1996. Quantitation of estolides by Fourier Transform Infrared Spectroscopy J. Am. Oil Chem. Soc. 73, 563-567.

Erhan SZ, Perez JM. 2002. Biobased industrial fluids and lubricants. AOCS Press, Champaign II.

Erhan SZ, Asadauskas S. 2000. Lubricant basetocks from vegetable oils. Ind. Crops. Prod. 11, 277-282.

Garcés R, Martínez-Force E, Salas JJ. 2011. Vegetable oil basestocks for lubricants. Grasas y Aceites 62, 21-28.

García-Zapateiro LA, Delgado MA, Franco JM, Valencia C, Ruiz-Méndez MV, Garcés R, Gallegos C. 2010. Oleins as a source of estolides for biolubricant applications. Grasas y Aceites 61, 171-174.

Garcia-Zapateiro LA. Franco JM, Valencia C, Delgado, MC, Gallegos, C. 2013. Viscous, thermal and tribological characterization of oleic and ricinoleic acids-derived and their blends with vegetable oils. $J$. Ind. Eng. Chem. 19, 1289-1298

Govindapillai A. Jayadas NH, Bhasi M. 2009. Analysis of the pour point of coconut oil as a lubricant base stock using differential scanning calorimetry Lubr. Sci. 21 13-26.

Guillen MD, Cabo N. 1997. Infrared spectroscopy in the study of edible oils and fats. J. Sci. Food. Agric. 75, 1-11.

Hagemann JW. 1988. Thermal behaviour and polymorphism of acylglycerides . In N. Garti \& K. Sato
(Eds.), Crystallization and polymorphism of fats and fatty acids. New York, Marcel Dekker Inc.

Isbell TA, Abbott TP, Asadauskas S, Lohr JE. 2000. Biodegradable oleic estolide ester base stocks and lubricants. Patent no US 6,018,063.

Isbell TA, Kleiman R, Plattner BA. 1994. Acid-catalyzed condensation of oleic acid into estolides and polyestolides. J. Am. Oil Chem. Soc. 71, 169-174.

Isbell TA, Kleiman R. 1994. Characterization of estolides produced from the acid-catalized condensation of oleic acid. J. Am. Oil Chem. Soc. 71, 379-383.

Isbell TA, Edgcomb MR, Lowery BA. 2001. Physical properties of estolides and their ester derivatives. Ind. Crops Prod. 13 11-20.

Jiang Z, Hutchinson JM, Imrie CT. 2001. Measurement of the wax appearance temperatures of crude oils by temperature modulated differential scanning calorimetry. Fuel, 80, 367-371.

IUPAC. 1992. Method 2.301. "Standard methods for the analysis of oils fat and derivatives".- 1st supplement to 7th edition, Pergamon Press, Oxford.

Morselli-Ribeiro MDM, Arellano DB, Ferreira-Grosso CR. 2012. The effect of adding oleic acid in the production of stearic acid lipid microparticles with a hydrophilic core by a spray-cooling process. Food Res. Int. 47, 38-44.

Mutlu H, Meier M. 2010. Castor oil as a renewable resource for the chemical industry Eur. J. Lipid Sci. Technol. 112 10-30.

Quinchia LA, Delgado MA, Valencia C, Franco, JM Gallegos C. 2010. Viscosity modification of different vegetables oils with EVA copolymer for lubricant applications Ind. Crop Prod. 32 607-612.

Quinchia LA, Delgado MA, Franco JM, Spikes HA, Gallegos C. 2012. Low-temperature flow behaviour of vegetable oil-based lubricants. Ind. Crop Prod. $\mathbf{3 7}$ 383-388.

Sánchez R, Franco JM, Delgado MA, Valencia C, Gallegos C. 2009. Development of new green lubricating grease formulations based on cellulosic derivatives and castor oil Green Chem. 11, 686-693.

Suzuki M, Ogaki T, Sato K. 1985. Crystallization and transformation mechanisms of alpha,beta-polymorphs and gamma-polymorphs of ultra-pure oleic-acid. J. Am. Oil Chem. Soc. 62, 1600-1604.

Van de Voort FR, Isamail AA, Sedman J, Dubois J, Nicodemo T. 1994. The determination of peroxide 
value by fourier transform infrared spectroscopy. J. Am. Oil Chem. Soc. 71, 921-926.

Vereecken J, Meeussen W, Foubert I, Lesaffer A, Wouters J, Dewettinck K. 2009. Comparing the crystallization and polymorphic behavior of saturated and unsaturated monglycerides. Food Res. Int. 45, 1415-1425.

Vlahov G. 1999. Application of NMR to the study of the olive oils. Prog. Nuclear Mag. Res. Spect. 35, 341-357.

Woerfel JB. 1986. Soapstock in Proceedings of the world conference on emerging technologies in the fats and oils industry, A.R. Baldwin (Ed.) AOCS Press, USA, pp. 165-168.

Yazicigil Z, Ahmetli G. 2008. Synthesis of the fatty acid compounds obtained from sunflower oil refining products. J. Appl. Polym. Sci. 108, 541-547.

Zerkowski JA. 2008. Estolides: From structure and function to structured and functionalized. Lipid Tech. 20, 253-256

Recibido: $30 / 1 / 13$ Aceptado: $23 / 5 / 13$ 